\title{
Holding the Accountability Problem Accountable: Response Mechanisms to Counter-Majoritarian Supreme Court Decisions
}

\author{
Dave Bridge \\ Baylor University
}

\begin{abstract}
If the Supreme Court rules against the wishes of the majority, how can that majority respond? I argue that while federal judges will never stand for election, majorities can employ various response mechanisms to counter-majoritarian decisions. I draw out observable expectations for inter-branch, local, and electoral responses. I then test these expectations in cases from the "mature" New Deal - communism, school prayer, busing, and abortion - showing the range of effective results achieved by anti-Court majorities. Given these results, I conclude that there is no "accountability problem"; there is just a narrow definition of accountability.

The author thanks Tim Burns, Clem Fatovic, Curt Nichols, David Nichols, and Dan Walters for their insights.
\end{abstract}

Less than three months after the Supreme Court decided Roe v. Wade, Representative Richard Ichord (D-MO) proposed a constitutional amendment stating, "The states shall have the power to regulate or forbid the voluntary termination of human pregnancy." A pro-choice advocate, Ichord believed that "liberalization of many of the state abortion laws was in order." And yet he sought to give conservatives a way around Roe. Why would a pro-choice Democrat attack the Supreme Court's pro-choice ruling? The answer comes in a single, blunt, and telling statement: "If the men who sit on the Supreme Court want to make laws, let them run for public office" (Congressional Record 1973: 10948).

This lack of electoral accountability for Supreme Court Justices has long been a complaint of scholars (Dahl 2003; Levinson 2008), politicians (Obama 2012, Romney 2012), and pundits (Beck 2008; Dowd 2012), all of whom have lamented the seemingly tragic helplessness of majorities thwarted by the judiciary. This article contends that majorities are not so helpless, and that defining accountability solely through direct elections views American democracy too narrowly. I argue that the constitutional system, void of judicial elections, nevertheless contains response mechanisms for counter-majoritarian judicial opinions. While majorities may not always overturn decisions, and federal judges will never stand for election, motivated majorities still hold the ability to counteract counter-majoritarian decisions. Specifically, majorities can legislatively attack the Court, underfund its mandates, obstruct local implementation, and politicize rulings in an effort to win elections.

I start by reviewing the counter-majoritarian and accountability accusations. Next, I turn to observable predictions about the polity's likely responses to these accusations. I use case studies from the mature New Deal — communism, school prayer, busing, and abortion — to show the various ways in which majorities can respond to counter-majoritarian decisions. The final section reviews the scope of these mechanisms, highlighting how the paper affects the contemporary study of American politics. 


\section{The Counter-Majoritarian Difficulty and the Accountability Problem}

It is helpful to distinguish between the "counter-majoritarian difficulty" and the "accountability problem." While distinct, they are also related and stem from the same source. Below, I describe the original critiques, as well as the scholarly response.

\section{Counter-Majoritarian Difficulty}

Published in 1962, Alexander Bickel's The Least Dangerous Branch created an "obsession" (Friedman 2002) among legal scholars regarding the counter-majoritarian difficulty. Bickel argues that judicial review is a "deviant institution." Because electorally accountable legislators make policy, we can be assured of that policy's majoritarian quality. ${ }^{1}$ When the Court strikes down these laws, it acts against the will of the majority. To Bickel, judicial review is, in a word, counter-majoritarian.

This aspect of Bickel's argument has created a loyal following, spawning a generation of judicial restraint advocates within legal scholarship (Choper 1980; Ely 1981) and jurisprudential thought and practice (Bork 1996; Scalia 1998). Political scientists, meanwhile, have taken issue with the charge of a counter-majoritarian Court. New wave "regime theory" has largely debunked the counter-majoritarian difficulty as a myth. Regime scholars argue that because the Court is part of the national governing regime (Dahl 1957; Gillman 2006a; Barnes 2007), it often uses judicial review in regime-friendly (i.e., majoritarian) ways (see Graber 1993; Gillman 2002; Lovell 2003). For instance, judicial review helped overcome entrenched Southern Democratic committee chairmen who almost single-handedly obstructed congressional efforts to desegregate (Klarman 1996; Powe 2000; McMahon 2004). Keith Whittington (2005) describes these instances as the Court "interposing its friendly hand"-striking down laws because the majority coalition wants the Court to do so.

\section{Accountability Problem}

While regime theory indicates that most instances of judicial review are not countermajoritarian, it does not say that the Court is never counter-majoritarian. Indeed, by examining public opinion polls and the make-up of the opposition coalition, we should be able to identify (admittedly rare) counter-majoritarian cases. In these instances, the counter-majoritarian difficulty is compounded by the accountability problem - that the Justices employing judicial review are not directly accountable to the electorate.

Basing his definition of democracy in majoritarianism via elections, Bickel predictably criticizes judicial review as not only deviant and counter-majoritarian, but also as undemocratic. Lemieux and Watkins (2009) critique Bickel for his narrow conception of democracy. American democracy, in particular, is not as simple as majority rule. Were Bickel to adopt a broader definition of democracy — one that includes accountability and tolerance of minority rights - he would not see judicial review in such a negative light. Similar to Lemieux and Watkins' (2009) charge of too narrow a definition of democracy, this paper argues that Bickel's definition of

\footnotetext{
${ }^{1}$ Granted, Bickel admits that other institutions in American constitutionalism (e.g., the Senate) have the potential to look and act in a counter-majoritarian fashion. Nevertheless, as the title indicates, his book is largely a criticism of the judicial branch.
} 
accountability (i.e., through, and only through, direct elections) is, again, not broad enough to capture the complexity of American constitutionalism. Judicial review can certainly protect minority rights, but it is still subject to some methods of accountability - even if those methods do not include direct elections.

\section{The Relationship Between the Court and Other Institutions}

The Constitution is a complex governing document that pursues the competing goals of accountability and tolerance of minority rights (Peretti 1999; Barnes 2003; Lemieux and Watkins 2009). Accountability requires mechanisms by which the people can guide, and respond to, government actions. Elections, of course, are the most direct mechanism; but other means exist, too. Tolerance of minority rights requires mechanisms to ensure that the majority cannot oppress minorities. An unelected Court empowered with judicial review is one such mechanism. With no electorate to win over, the Court can issue rulings that protect minorities (e.g., Loving v. Virginia). And while the Justices employing judicial review might be pursuing the tolerance of minority rights, they are still subject to mechanisms of accountability. Put differently, the Constitution not only creates an unelected judiciary that can protect minorities, but it also ensures that the courts have some measure of accountability to the rest of the constitutional system. I do not mean to say that Supreme Court Justices can be held to Bickel's standards of accountability (i.e., direct elections). That claim is indefensible. Rather, I argue that there is more than one way for a majority to effectively respond to a counter-majoritarian Court ruling.

Indeed, a growing trend in the regime politics paradigm emphasizes its

founders' (Shapiro 1964; McCloskey 2000) premise that the relationship between the Court and the rest of the political system is a two-way causal street. Some have taken after Robert McCloskey, who introduced the notion that the role and behavior of the Court "reflect[s] constellations of power and interest within changing historical contexts" (Gillman 2006b: 338). Scholars use Dahl's classic (1957) article on "the Supreme [a]s inevitably part of the dominant national alliance" as their launch point by looking at negative cases - instances in which the Court does not simply follow the will of the dominant coalition. In fact, in the modern era, there might be reason to think that divided government (Tushnet 2003), increased factionalization within parties (Lemieux and Lovell 2010), and/or polarization (Keck 2014) has made it difficult for coalitions to consolidate their power in the same way that, say, the New Deal coalition did. In such an environment, Supreme Court Justices might enjoy more "political safeguards": protections afforded by some group of elected officials who agree with a particular ruling (Clayton and Pickerill 2004; Pickerill and Clayton 2004). Nevertheless, even under these conditions, this strand of work reminds us that other institutions can still push back against the Court. Be it Nixon's law and order campaigns (McMahon 2011), George H.W. Bush's efforts to overturn Roe (Keck and McMahon, forthcoming), or Clinton's efforts to work within the confines of a conservative "constitutional order" (Tushnet 2003), these scholars identify instances in which elected officials have responded negatively to Court decisions.

Meanwhile, those working within the law and society literature have employed Martin Shapiro's notion of "political jurisprudence," which advocates studying the effects of politics and policy on the courts, and the effect of courts on politics and policy (for an overview, see Gillman 2004). This body of work investigates the effectiveness and development of courts under 
varying conditions. Scholars in this tradition examine the development of law (Silverstein 2009), litigation (Barnes 2011), rights (Burke and Barnes 2009), and court decisions (Hall 2011). The operating assumption of this body of work is, as Barnes and Burke put it, that "courts, like legislatures and executive branch agencies, are policymakers" (2015: 6). And judicial policy and judicial politics are "the product of a dialogue of courts, legislators, policy entrepreneurs, opinion leaders, the general public, and individual litigants. Sometimes, this is a cooperative process; sometimes, it is antagonistic" (Silverstein 2009: 5). Below, I describe expectations of the more antagonistic elements of the process.

\section{Expectations for Counter-Majoritarian Decisions}

The Constitution contains direct and indirect response mechanisms. A holistic document, the Constitution creates institutions that work both with and against each other. It is in this inherent, purposeful tension that we find the ways in which the constitutional system provides majorities with response mechanisms to counter-majoritarian decisions. Specifically, I describe three responses: inter-branch, local, and electoral options. In the sub-sections below, I lay out each responses' constitutional origin, their application to Court, and the observable expectations for response mechanisms to counter-majoritarian decisions.

\section{Inter-Branch Response Mechanisms}

The Constitution gives Congress and the president prescriptions for checking judicial power, which we might expect following a counter-majoritarian decision. I discuss three methods. First, other scholars have written about Article III's provision for Congress' ability to regulate the Court's appellate jurisdiction (Clark 2010; Engel 2011; Nichols, Bridge, and Carrington 2014). If judicial decisions upset majorities, then we might observe effective and/or more voluminous congressional court-curbing attacks. ${ }^{2}$ In addition, Alexander Hamilton's famous line, "the judiciary...has no influence over either the sword or the purse" (Federalist 78), leads to two other observable expectations. The first of these two expectations is Congress reducing the funding necessary to effectuate a Court ruling. The second is the president affecting Court mandates through the nature and extent of execution. Thus, we might expect Congress to tighten the purse strings and the president to be unresponsive in executive enforcement.

\section{Local Response Mechanisms}

In addition to the horizontal check of three ambitious branches, there is also a vertical check between the federal and state governments. In large part, states can balance power against the national government through self-governance and local execution of laws. In Federalist 46, James Madison noted that state authorities could form "very serious impediments," including "refusal to cooperate," to federal policy. We might expect this type of obstruction to come from a number of state and local institutions. For example, state legislatures could pass bills that scale back the Court's opinion. Local institutions (e.g., city councils) or officials (e.g., police officers)

\footnotetext{
2 In the case studies, I use the Nichols, Bridge, and Carrington (2014) database to identify the number of courtcurbing proposals. The database is the most recent and extensive. It is also the only database to list the political issue (e.g., school prayer, abortion) in question.
} 
can dispute or disregard the Court, all the while hindering on-the-ground implementation. In addition, local communities - the people themselves - can defy Court orders, making implementation nearly impossible. In sum, if local majorities oppose the Court, then we might expect them to employ some of the response mechanisms that result in half-hearted, or failed, execution.

\section{Electoral Response Mechanism}

Counter-majoritarian decisions may result in the anti-Court majority electing new politicians who campaign on combating the judiciary. While the people cannot simply vote the Justices out of office, they can choose new legislators who promise to curb the Court, defund its mandates, confirm certain types of Justices in the future, etc. Thus, we might expect an unpopular decision — or, more likely, a string of counter-majoritarian decisions — to spur the majority to seek remedy via elections. More specifically, we might observe one party building a new winning platform around anti-Court rhetoric.

\section{Case Selection}

Before discussing the case studies, their collective selection warrants a brief explanation. I use communism (1956-1957), school prayer (1962), busing (1971), and abortion (1973), mainly because recent research points to "mature" New Deal counter-majoritarian examples (Nichols, Bridge, and Carrington 2014; see also Powe 2000; Friedman 2002). ${ }^{3}$ While "it is extremely difficult to know as a matter of simple mathematics whether the Court was acting at any given time in a counter-majoritarian fashion" (Friedman 2002, 349), we still might expect some observable manifestations of counter-majoritarianism. In particular, each issue area exhibits public opinions polls ${ }^{4}$ and cross-partisan coalitions ${ }^{5}$ that point to a majority opposed to the Court's decision(s).

I use these cases in a theory-building effort to highlight the response mechanisms available to majorities that oppose judicial decisions. The main advantage is that the cases clearly show how these mechanisms can be used successfully. The cases are not meant to assert a definitive claim that counter-majoritarian decisions are always reversed in one manner or another. Rather, they are meant to show the response mechanisms available to energized majorities. As with most new theories involving the counter-majoritarian difficulty (Graber 1993; Gillman 2002; Lovell 2003), the timeframe is admittedly limited. But also similar to

\footnotetext{
${ }^{3}$ All these cases show the Court issuing a ruling that aligns with Liberal Democratic preferences, despite the fact that Republicans made a number of appointments to the Bench. Ultimately, though, it does not matter who appointed the Justices. What matters is the bottom line: that the Court issued counter-majoritarian decisions in these cases.

${ }^{4}$ For instance, at the time of the respective cases, $74.7 \%$ had a "very favorable" or "favorable" view on the House on un-American Activities Committee (NORC 1954); 70\% disapproved of the Court banning school prayer (Gallup 1963); 73\% opposed busing (Gallup 1971); and 65.5\% opposed laws permitting abortions (at all) after the first trimester (Blake 1977).

5 The evolution of these coalitions is discussed below.
} 
previous work, I concentrate on developing the scaffolding that allows for broader application in future work.

\section{Communism}

In 1956-1957, the Supreme Court restricted state and federal government policies toward suspected communists. For example, Sweezy v. New Hampshire narrowed the definition of "subversive persons" to exclude activity remotely or unconsciously connected to subversion. In Watkins v. United States (1957), the Court chided the House on Un-American Activities Committee (HUAC) for reaching beyond its constitutional power. ${ }^{6}$ In ruling against the government, the Court upset Republican and Southern Democratic members of Congress, and in 1958, a cross-partisan alliance of these two groups effectively halted the development of any further pro-communist jurisprudence. By 1959, the Court reversed some of its earlier decisions.

\section{The Inter-Branch Response}

The main response mechanism to the 1956-1957 communist cases was congressional attacks on the Court. Shortly after the 1957 decisions, Republicans and Southern Democrats formed a cross-partisan alliance. Republican preferences were straightforward: they vehemently opposed the rulings. For example, when Chief Justice Earl Warren asked President Eisenhower what Warren should do with the communists, Eisenhower responded, "I would kill the SOBs" (Warren 1977).

Southern Democrats, on the other hand, opposed the communism decisions, in part, because they saw supposed ideological and organizational links to desegregation. Senator James Eastland (D-MS) spearheaded the campaign. As head of the subcommittee on internal security, Eastland held hearings on Communist Party activity in the South. The hearings included witnesses forcibly dragged in and out of proceedings, federal marshals breaking up fistfights, and one witness suffering a heart attack amidst a scuffle. In parts of the South, ostensibly anticommunist measures (e.g., registration laws) really targeted blacks. In Louisiana, for example, the state legislature passed police-enforced segregation, because, as one state legislator put it, "white control has receded all over the world while communism has advanced" (Woods 2004).

Although Republicans were skeptical of allying with segregationists (Friedman 2002), the alliance proved successful in pursuing its anti-communism aims. Together, Southern Democratic and Republican members of Congress introduced six court-curbing proposals. One of them, co-sponsored by Senators William Jenner (R-IN) and John Butler (R-MD), restricted the Court's jurisdiction in communism cases. The bill passed in the House of Representatives, 249147. Republicans voted nearly three-to-one (142-44), while Southern Democrats accounted for 94 of the 107 Democratic ayes. In the Senate, the bill failed, 40-41, with support coming exclusively from Republicans and Southern Democrats (see appendix). In reality, Senate

\footnotetext{
6 In other cases, the Court protected the rights of lawyers (Konigsberg v. State Bar, 1957, and Schware v. Board of Bar Examiners, 1957), federal employees (Cole v. Young, 1956), professors (Slowchower v. Board of Education, 1956), and foreign service officers (Service v. Dulles, 1957). Other cases regulated the prosecution of suspected communists (Pennsylvania v. Nelson, 1956; Jencks v. United States, 1957; Yates v. United States 1957).
} 
Majority Leader Lyndon Johnson accidentally prevented the bill from possibly passing. ${ }^{7}$ Practically, even though the bill did not pass, it still produced the intended effect.

Put simply, the Jenner-Butler bill caused the swing Justices to "duck controversy by changing direction" (Friedman 2002: 196). Following the 40-41 vote, Justice Felix Frankfurter led the charge to postpone any communism cases on the Court's docket. Earl Warren later alleged, "Felix changed on communist cases because he couldn't take criticism" (Newman 2001: 677). In 1959, Frankfurter and Justice John Marshall Harlan II "retreated” (Tushnet 1993: 6) from their earlier votes. Specifically, Uphaus v. Wyman overruled Sweezy v. New Hampshire, reestablishing New Hampshire's original definition of "subversive persons" to include those remotely or unconsciously connected to subversion. In addition, Barenblatt v. United States reversed Watkins v. United States by ruling that HUAC had not transgressed First Amendment rights. Gerald Rosenberg sums up these cases: "While there are differences between Sweezy and Uphaus... [and] Watkins and Barenblatt, too much should not be made of them. The bottom line was that in response to congressional preferences, the Court effectively reversed its earlier decisions" (1992: 391). While some facts might have been different, even Earl Warren recognized that "Sweezy was exactly the same thing as Barenblatt" (Newman 2001: 677). ${ }^{8}$

\section{Response Mechanisms Revisited}

The communism cases demonstrate a powerful inter-branch response mechanism: courtcurbing. The fact that the Jenner-Butler bill fell two Senate votes short does not suggest that Congress failed to influence the Court's behavior. As Rosenberg notes, "Enactment of courtcurbing bills is not necessary to curb the Court" (1992: 391). Thus, the communism case study shows that majorities can use court-curbing (or the threat thereof) as an effective response mechanism to counter-majoritarian decisions. In this instance, the inter-branch response stopped the Court from hearing more cases; and eventually, it caused swing Justices to reverse the original counter-majoritarian decisions. While the Justices were not removed from office, congressional saber rattling produced the intended effect.

\footnotetext{
${ }^{7}$ To be sure, LBJ did not want the bill to pass. But harboring presidential aspirations, LBJ wanted to force a tie, whereby Vice President Richard Nixon (the likely Republican candidate) would have to cast a vote. A procommunism vote would upset Nixon's conservative base, while an anti-communism vote would put off swing voters. In whipping votes, LBJ predicted a 40-40 tie. Unexpectedly, Wallace Bennett (R-UT) voted against the bill, thereby tabling the measure. Ironically, it was LBJ's scheming itself that ultimately dashed the tied vote. During the roll call, LBJ tricked anti-communist Robert Kerr (D-OK) into the cloakroom (Engel 2011: 298). Kerr's vote would have offset Bennett's, and forced Nixon's hand. Nixon, too, played a role in parliamentary procedures. Once Kerr rightfully entered chambers, Strom Thurmond (D-SC) called for a re-vote. Assuming his President of the Senate duties, Nixon (who did not want to cast a vote) cut Thurmond off, "The motion is not debatable" (Congressional Record 1958, 18928).

8 The quote comes from Drew Pearson's diary. Pearson was a prominent liberal journalist who covered the Warren Commission. The quote seems a bit off. It should probably read either, "Sweezy was exactly the same thing as Uphaus," or, "Watkins was exactly the same thing as Barenblatt." Regardless, the tone shows that the Chief Justice believed the Court had reversed its earlier decisions.
} 


\section{School Prayer}

In Engel v. Vitale (1962), the Court ruled that New York schools' voluntary prayer violated the Establishment Clause. A national pro-prayer majority emerged, and though it did not reverse the ruling (as in communism), the majority responded in ways that had both shortand long-term effects. Below, I discuss the local, inter-branch, and electoral reactions to the counter-majoritarian ruling.

\section{The Local Response}

One immediate reaction to Engel was widespread on-the-ground resistance. Local communities, school districts, and school boards refused to do away with their daily prayer. Unsurprisingly, the Bible Belt was the most resistant region, yet non-compliance spread beyond the South. For example, one survey found that $95 \%$ of Midwestern superintendents had not changed their districts' policy on prayer following the decision. As one superintendent put it, "We plan to continue until forced to stop" (emphasis in original, Dolbeare and Hammond 1971, 42). In Long Island, where Engel had originated, the American Legion printed 100,000 pamphlets containing a short prayer. The group distributed them in schools, encouraging students to defy the Court by reciting the prayer each morning in class.

While some districts continued to pray, others found loopholes in the Court's ruling. In Florida, teachers read daily passages from the Bible, while not commenting on them (see Chamberlin v. Dade County). In DeKalb, Illinois, one teacher led a (supposedly secular) daily “thankfulness" recitation. ${ }^{9}$ Later, moment-of-silence laws would push back against Engel, as pro-prayer forces turned away from led prayer and toward a prescribed time when students could pray on their own.

Despite the decision, schoolchildren across the country continued to pray each morning, with local policy-makers and bureaucrats either encouraging or allowing it. Senator Eastland (DMS) had offered a correct prediction: "Frankly, I don't believe that the schools of America are going to stop their morning devotions." 10 One study succinctly describes the effect of Engel $v$. Vitale: "Whatever was being done before 1962 or $1963 \ldots$ was apparently still being done in 1964" (Dolbeare and Hammond: 42). At the time, pro-prayer majorities did not merely accept the Court's judgment. They either actively opposed or effectively disregarded the decision in their local schools.

\section{The Inter-Branch Response}

On the very day the Court issued Engel, Frank Becker (R-NY) proposed the first constitutional amendment seeking to overturn the decision. And if measured by the number of court-curbing proposals, Engel v. Vitale is the most attacked decision in Supreme Court history. In the decade following the ruling, Congress launched 497 attacks, with 279 from Republicans, 143 from Southern Democrats, and 75 from non-Southern, presumably Catholic-representing,

\footnotetext{
${ }^{9}$ It read: We thank you for the flowers so sweet; We thank you for the food we eat; We thank you for the birds that sing; We thank you for everything. See DeSpain v. DeKalb.

${ }^{10}$ Never one to pass up an opportunity to decry desegregation, Eastland continued, “And I don't believe the President is going to call out the troops" (Dierenfield 2007: 148).
} 
Democrats. In those ten years, the primary means of attack was a constitutional amendment proposing to place school prayer beyond the scope of the Establishment Clause. In separate instances, the Senate and House voted on whether to adopt the amendment. In 1966, the Senate voted 49-37 (57.0\%). In 1971, the House voted 240-163 (59.6\%) (see appendix). In both roll calls, a majority favored the amendment; yet they both fell short of the requisite two-thirds margin needed for constitutional amendments. With both bills, Catholic-representing Democrats joined the Republican-Southern Democrat alliance. In the House vote, for example, $40 \%$ of all Democratic ayes came from the North (compared to the communism vote, in which Northern Democrats accounted for only $12.1 \%$ of ayes). In addition, more than a third of those Northern Democratic votes came from the five states with the highest percentage of Catholics (CT, NJ, NY, MA, and RI).

After the attackers failed to muster a two-thirds majority, they turned to the strategy that had worked after the communism cases: jurisdiction stripping, which required only simple majorities from both chambers. Social conservatives sought to take away the appellate jurisdiction of federal courts on issues regarding school prayer. For example, one bill stated that "[t]he Supreme Court shall not have jurisdiction to review... any case... which relates to voluntary prayers in public schools." Ultimately, these bills stalled in the Senate Judiciary Committee, contributing to the anti-Engel majority's frustration. And while the inter-branch response on prayer did not result in a new constitutional amendment, jurisdiction stripping, or jurisprudential about-face (as with communism), it did help to highlight a major, latent fault line in the Democratic Party. The Republican Party took advantage of the rift.

\section{The Electoral Response}

The turn to social issues with religious overtones contributed to a new GOP strategy that would, eventually, play a role in building a Republican majority. The key was converting enough Southern and Catholic Democrats. The Democratic Party already had a tenuous relationship with Southerners, who were opposed to the Liberal wing's civil rights stance, with bills (e.g., the Civil Rights Act of 1957) and Court rulings (Brown v. Board) occasionally disrupting the coalition. The communism decisions (which Southerners linked to desegregation) widened the fault line. School prayer widened it too, as Southern Democrats linked prayer to communism. For instance, L. Mendel Rivers (D-SC) charged, "I know of nothing in my lifetime that could give more aid and comfort to Moscow than this bold, malicious, atheistic and sacrilegious twist" (Congressional Record 1962, 11732; see also pp. 11775, 11718, 12332). In sum, Engel deepened the ire of a skeptical Southern base within the Democratic Party. While on its own it probably did not transform the South into a Republican bastion, the issue of school prayer nevertheless contributed to Southern realignment.

Meanwhile, the Court's ruling also seemed to open a new fault line with non-Southern Catholic Democrats, who also held traditionalist views on social issues-especially school prayer. For their part, Republicans altered their focus, rhetoric, and strategy in an attempt to attract Catholics. As soon as 1964, the GOP platform added a plank calling for a pro-prayer constitutional amendment. During the presidential campaign that year, Barry Goldwater questioned whether "this is the time in our nation's history for our federal government to ban Almighty God from our school rooms" (Williams 2010). Soon thereafter, conservative 
intellectuals pushed for the Republican Party to look where the "backlash against liberal social policies erupted first... in Catholic ethnic neighborhoods" in order to build "a new unity... which placed Protestants and Catholics in the same camp against 'secular' forces" (Nash 1976; Gottfried 1992; Miles 1980).

As time passed, officials in the Republican Party identified school prayer as a winning, majoritarian issue. One administration memo, entitled "Dividing the Democrats" (1971), stated, "Favoritism toward things Catholic is good politics." In 1972, Nixon staffer Pat Buchanan's "Assault Strategy" explicitly advocated attacking Democrats on "Catholic/ethnic" issues, including religion in schools. Thus, even though the court-curbing proposals did not pass, they served as a signaling mechanism between the GOP and potential Catholic Democratic defectors. By 1980, enough Catholics converted to help give the GOP a slim, but effective, national majority. ${ }^{11}$

\section{Response Mechanisms Revisited}

The most effective response to Engel took place at the local level, where the local bureaucrats (e.g., teachers and school administrators) kept prayer in the classroom. While Congress never reversed the decision nor curbed the Court's jurisdiction, the proposed amendments and attacks eventually carried over into the electoral response. In the late 1970s, and especially 1980, many Catholic Democrats started voting Republican (Ryan and Milazzo 2014). This is not to say that there was an 18-year delay between Engel and its countermajoritarian effects. Indeed, local resistance was immediate. But Engel was part of - and perhaps the start of - a slow-motion erosion of the New Deal coalition. After the decision, the major rift in the Democratic Party was not just North-South; it was Liberal-traditionalist. This threatened to divide Liberals not only from Southerners, but from all traditionalist co-partisans, including Catholics. The rift persisted when the Court issued future decisions that further split traditionalists and Liberals.

\section{Busing}

Perhaps more than any other case in this study, Swann v. Charlotte-Mecklenburg Board of Education demonstrates virulent majoritarian responses. In ruling that federal courts could mandate municipal busing, the Court sent shockwaves throughout the country. The impact was not limited to the South, as it touched upon Northern suburbs, where many citizens had already opposed the school prayer decisions. Similar to the response to the court's decision on school prayer, the response to the counter-majoritarian busing decision included short-term local and inter-branch responses, as well as a long-term electoral response.

\footnotetext{
${ }^{11}$ I adopt the increasingly accepted notion that 1980 represents an electoral realignment (Crockett 2002; Skowronek 2011; Nichols 2012; Bridge 2014). In addition to capturing the presidency and Senate, Reagan "ran ahead" (Schick 1982) of Southern Democrats. With an effective majority in the lower chamber, the House consistently backed Reagan's preferences (e.g., budget passage, tax cuts). The transformation of the South into a durable Republican stronghold began in the 1960s-1970s. In 1980, the Republican Party gained its largest share of Southern House seats since Reconstruction (36\%). Today, Republicans hold 73\% of Southern House seats. The similar change in Catholics' votes came at the same time (see Ryan and Milazzo 2014).
} 


\section{The Local Response}

As had been the case with the prayer decision, some local school districts and parents made implementation of Swann nearly impossible. Many have described the failure of busing in Northern (Metcalf 1983; Taylor 1998) and Southern cities (Pratt 1992; K'Meyer 2013). Local communities simply resisted busing, the most famous examples coming in Boston and Detroit.

No city sparked more controversy than Boston, where more than 22,000 white students left the Boston school system. Local officials joined residents in their opposition to busing. For instance, Boston's mayor declared, "I'm for integration, but against forced busing." Though instructed to do so, the Boston School Committee refused to name a desegregation coordinator. In addition, the Committee asked teachers to distribute leaflets calling for parents to support a 25,000-person anti-busing protest, in which the city police sympathized with the protesters by wrapping ribbons around their handlebars. Eventually, an uglier side took over, as messages such as "Niggers Go Home" and "This is Klan Country" were spray painted on bus routes bringing blacks into the white suburbs. At one school, a mob threw rocks and bottles at incoming blacks while chanting, "Die, Niggers, Die." In one infamous (as well as photographed) episode, a black man was struck with the pole carrying an American flag (Metcalf 1983; Theoharis 2002).

The subversive defiance of Detroit was typical of enraged majorities throughout US cities. For example, in Macomb County, an anti-busing group named Save Our Children recruited 10,000 members and called for a boycott of busing, resulting in 20,000 students not showing up to school. Parents and school boards seemingly worked together to avoid busing. For instance, a Detroit school board member proudly cited over 8,500 correspondences from concerned parents, with only six supporting the new busing measures. The board also allowed local parents to form a private school that used public school facilities after hours. The pressure extended statewide, too. Before Swann, every white Michigan member of Congress voted against spending cuts for busing. After Swann, all but one of them switched their vote (Metcalf 1983). Richard Nixon summarized the anti-busing sentiments in the Motor City: "The Detroit case is perhaps the most flagrant example that we have of all the busing decisions" (Nixon 1972a).

\section{The Inter-Branch Response}

After Swann members of Congress vigorously attacked the Court on the busing issue. Once again, the attacks came from both parties and sections. Of the 227 court-curbing proposals related to busing, Democrats launched 127 (55.9\%). Of those 127, Southern Democrats accounted for $91(71.7 \%)$. The other 36 non-Southern Democratic attacks shared a common trait: they came after a lower federal court ruled to use busing in a Northern city. For example, Michigan members of Congress proposed five court-curbing resolutions after the Detroit Federal District Court ordered busing. Rulings in Dayton, Indianapolis, and Wilmington led to proposals by members of Congress from Ohio, Indiana, and Delaware, respectively. ${ }^{12}$ Republicans, for their part, contributed 100 attacks.

\footnotetext{
12 The cases are as follows: Detroit (Bradley v. Milliken, 1972); Dayton (Dayton v. Brinkman, 1977); Indianapolis (US v. Board of Commissioners, 1971); and Wilmington (Evans v. Buchanan, 1976).
} 
Although Congress never explicitly curbed the Court on busing, the legislature did pass two other measures that scaled back the ruling. First, Congress postponed the implementation of Swann until all appeals cleared the judicial system. The measure passed with bipartisan support (235-125), with Republicans voting 129-17, and Democrats voting 106-108. Of the 106 Democratic supporters, 57 came from the South and 49 from the North. Second, Congress passed a resolution forbidding the use of federal money to implement busing. The voting patterns were nearly identical to postponement: 234-124 with 125 Republicans, 66 Southern Democrats, and 43 Northern Democrats in the majority (see appendix).

Finally, the response to Swann contains an interesting executive branch response. Specifically, while the Nixon and Ford administrations did not outright defy executive responsibilities, they also did not go out of their way to actively implement Swann or other lower federal court decisions calling for busing. Nixon (1971) had called for postponement and defunding even before Congress introduced the amendments. In addition, one of the GOP's chief strategists, Kevin Phillips, explored the possibility of Nixon publicly refusing to enforce busing. Citing polls that indicated "people all over the United States are fiercely opposed to busing," Phillips hinted that Nixon would electorally benefit by defying the Court (1972a). In the end, Nixon reluctantly "okay[ed] the law while rolling his eyes for all white Southerners to see" (McMahon 2011: 75). After Nixon's resignation, Ford continued executive avoidance. In fact, during the Boston saga, Ford announced his opposition to busing and his intention to avoid enforcement (Ford 1974). The mayor of the city interpreted Ford's comments and actions as saying, "You're on your own in the implementation of federal court orders" (The Bulletin 1974).

\section{The Electoral Response}

As with the response to Engel, Republicans consciously used Swann to try to build a new majority coalition. Through congressional attacks on the Court, party platforms, ${ }^{13}$ and presidential statements, ${ }^{14}$ the GOP repeatedly signaled their staunch opposition to busing. More telling, Republican strategists intentionally planned to take advantage of the counter-majoritarian decision by courting Southern and suburban Democrats. A memo entitled "Dividing the Democrats" said the "dividing line [in the South] is essentially that of the race issue... which does not sit well with the essential 'suburban conservatism'... of Democrats in the South." The memo encouraged "elevation of the issue of compulsory school integration...via 'bussing' [sic]." As the head of the North Carolina Republican Party commented, "It's race in North Carolina... The Democrats by and large were pro-busing" (Rouse 1997). The same was likely true in the rest of the South.

Meanwhile, the GOP also preyed on wavering Northern Democrats. A memo by Pat Buchanan focused on possible Democratic presidential candidate Senator Edmund Muskie (ME). Buchanan wanted to force "Muskie to take the kind of stand that would either alienate the

\footnotetext{
13 In 1972, the GOP Platform read, "Busing fails its stated objective_-improved learning opportunities." (The Democratic Platform stated, "Transportation of students is another tool to accomplish desegregation.) In 1976, the GOP Platform proclaimed, "We oppose forced busing...the Democrat-controlled Congress has failed to enact legislation to protect this concept."

14 “I am against busing” emerged as a Nixonian mantra (Nixon 1971; 1972b; 1972c).
} 
suburbanites...or appear again as an appeaser of the Right in the eyes of the professional liberals." Either way, Buchanan believed "'forced busing'... [could] be publicly hung around the neck of the Democratic candidate" (Hillygus and Shields 2008: 131). The "Dividing the Democrats" memo referred to this as putting "Northern liberals like Muskie on an untenable hook." Congressional Watergate testimony later revealed some of the tactics used to employ this partisan strategy. For instance, the Committee to Re-Elect the President (CREEP) hung posters that read, "Pro-Busing Ed's [Muskie] Kids Go to Private School." More shocking, CREEP invented the entirely fictitious interest group Mothers Backing Muskie Committee. Under the auspices of this non-existent group, CREEP hung posters saying, "Help Muskie in Busing More Children Now" (Segretti 1973). The Nixon tapes indicate that these efforts might have been the direct brainchild of Nixon (see McMahon 2011: 107).

\section{Response Mechanisms Revisited}

The response to Swann v. Charlotte demonstrates a wider array of response mechanisms expectations than any other case study. For starters, grassroots opposition was steadfast, as local parents, teachers, and school boards refused to cooperate with the Court's decision. At the interbranch level, both Congress and the president presented obstacles. Court-curbing proposals and postponement both sought to limit the immediate impact of Court-mandated busing. More prominently, by cutting funding, Congress made it even easier for resistant suburbs to avoid busing. In the executive branch, Nixon's condemnation and Ford's indifference toward Swann gave school boards the ability to ignore the Court. Finally, while busing did not shake the same moral values fault line as Engel v. Vitale, it nevertheless dissatisfied the same groups. It certainly displeased Southern Democrats, and probably upset suburban Catholics, too (e.g., Bostonians). ${ }^{15}$ As the Republican Party responded to these traditionalist concerns, Swann v. Charlotte-and soon thereafter, Roe v. Wade-played an important role in electoral realignment.

\section{Abortion}

In Roe v. Wade, the Court ruled that the right to privacy covered the right to an abortion during the first trimester of pregnancy. In the second trimester, states could allow, restrict, or regulate abortions. While one cannot say with confidence that a pro-life majority existed, polls indicate that a majority was opposed to the details of Roe. ${ }^{16}$ This ruling shook the same moral values fault line as the school prayer decision, when Southern and Catholic Democrats allied with Republicans. The majoritarian response to Roe, therefore, was similar to Engel's local, inter-branch, and electoral responses.

\footnotetext{
15 Interestingly, Ryan and Milazzo (2014) note that during this period, Catholics started moving to the suburbs.

16 Graber (1993) and Lemieux and Lovell (2010) accurately contend that a majority of policy-makers willfully passed the buck on abortion. I do not dispute this claim. I only add that it is possible that at the time of the decision, local, legislative, and electoral majorities might have opposed the particulars of Roe. To wit, two months before the Roe decision, 58\% of Americans stood against liberalizing abortion policy (Gallup 1972). Although respondents were split almost evenly on first trimester abortions (Harris 1972; Gallup 1973), 65.5\% opposed laws permitting women to have an abortion after the first trimester (Gallup 1973; see also Blake 1977). While this points to a possible pro-life majority, I make the more qualified claim of an anti-Roe majority. Furthermore, McMahon (2011: 177) points out that Nixon, and other GOP strategists, were cognizant of the post-Roe political opportunities.
} 


\section{The Local Response}

Gerald Rosenberg argues that Roe v. Wade did not lead to short-term social change in abortion rights. While Matthew Hall (2011) has shown that the rate of abortions did, in fact, increase immediately after Roe ${ }^{17}$ local responses were still available. Put simply, many local officials worked to counteract the ruling. While the sum of these efforts might not have constituted a national majority, they likely operated with a majority of local support. In some states (e.g., ND, RI, AR), abortion could be used only to save the life of the woman. In Louisiana, the attorney general threatened to take away the license of any doctor performing an abortion. The city attorney in St. Louis threatened to arrest such physicians. State legislatures, too, moved to restrict abortions. For example, in the year following Roe, state legislatures introduced 189, and passed 19, bills regarding abortion. Almost all of these bills were deterrents to abortion (Black 1977: 61), requiring steps such as parental consent, mandatory counseling, or waiting periods. After Roe, state governments closed facilities offering abortions, discouraged insurance companies from covering abortions, and restricted residency programs from providing abortion training. Second trimester abortion availability, coverage, and training were even rarer (Rosenberg 1991). On the whole, Roe might have made first-trimester abortions more available (Hall 2011), but as a 1984 study commented, because of state laws, "many women still find it difficult or impossible to obtain abortion services" (Henshaw, Forrest, and Blaine 1984, 122).

\section{The Inter-Branch Response}

Court-curbing attempts for abortion reveal a different pattern than attempts against decisions on prayer or busing. Namely, attacks came almost exclusively from Republicans and non-Southern Democrats. Of the 233 total court-curbing proposals stemming from abortion, Republicans contributed 128. Of the 105 Democratic attacks, non-Southern members of Congress proposed 97. Stunningly, only eight attacks came from Southern Democrats. Regardless, as with busing, the most effective congressional responses came through legislative resolutions rather than court-curbing or proposed constitutional amendments.

The first major congressional response established a federal right-of-conscience law, which prohibited hospitals from compelling their employees to perform abortions. The bill passed with overwhelming bipartisan support in the House (369-40) and Senate (92-1) (see appendix). Today, 46 states have some version of a right-of-conscience law. Furthermore, 14 states have passed laws allowing individuals, pharmacists, and/or hospitals to refuse to distribute contraceptives.

The most impactful abortion legislation dealt with funding, as Congress voted twice to limit the federal government's ability to spend money on abortion-related issues. First, the House added an amendment to the incorporation of the Legal Services Corporation - which was started to help those who needed, but could not afford, legal counsel. The amendment dictated

\footnotetext{
${ }^{17}$ Hall (2011) separates the data into states that did or did not allow abortions before Roe. Those that did not allow abortions before Roe saw a dramatic spike immediately after the decision. Those that did allow abortions before 1973 witnessed a slight drop in abortions after Roe. Hall wisely explains the latter: abortions in states that allowed abortion before Roe were artificially high because they attracted out-of-staters who could not obtain an abortion in their home state. Once Roe granted more access, women seeking an abortion had no need to go outside their home state.
} 
that no funds could be used for any litigation that sought to procure an abortion or provide facilities for an abortion. It passed 301-68. More broadly, in 1973, Representative Henry Hyde (R-IL) introduced the first iteration of the Hyde Amendment, a provision barring the use of federal money to pay for abortions. Introduced in the House, it passed 207-167, with 94 of 128 Republicans and 113 of 246 Democrats voting in favor. Of the 113 Democrats, only 49 represented the South (see appendix). In addition, more than a third of all non-Southern Democratic "ayes" came from the five states with the largest proportion of Catholics. Altogether, even though Congress never reversed or officially sanctioned the Court, the legislature still responded in ways that scaled back the original ruling.

\section{The Electoral Response}

Republicans again saw an opportunity to take advantage of a counter-majoritarian Supreme Court decision. The congressional attacks were part of a strategy to reach out to Southern, and especially, Catholic, Democrats. Top Republican strategists bet that a strong prolife stance would gain more partisans than it would lose. One internal Nixon administration memo summarized the situation: "There is a trade-off, but it leaves us with the larger share of the pie." Specifically, Kevin Phillips (1972b) noted that "betting on traditional values" would alienate "upper-middle and upper-class GOP liberals"; but it would gain Southerners and "woo conservative Catholics." When challenged on taking a pro-life stance, Pat Buchanan fired back that Nixon would "cost himself Catholic support and gain what? Betty Friedan?" (Mason 2004: 155). Instead, Buchanan advocated that the GOP use abortion to force the Democratic Party to choose between "tens of millions of Catholic supporters... [or] their liberal friends at the New York Times" (Buchanan, 1971).

The Republican Party continued to highlight the widening moral values fault line that originally emerged with school prayer. With Roe v. Wade, the same disaffected groups (Southerners and Catholics) became even more alienated from the Democratic Party on religious issues. If anything, abortion was (and probably still is) more salient than school prayer. This is not to say school prayer did not matter; but abortion was likely a more polarizing subject. And by 1980 , traditionalist Democrats responded to Roe - or, perhaps more appropriately, to the string of Liberal rulings - by voting Republican.

\section{Response Mechanisms Revisited}

The reaction to Roe contains all three of the observable response mechanisms. First, state-level regulation had the intended effect of discouraging abortions (Blake 1977; Rosenberg 1991), thereby demonstrating effective local responses. Meanwhile, Congress countered with right-of-conscience laws, as well as tightening the purse strings to cut federal funding to nearly all abortions. Court-curbing attacks, along with other signaling efforts, also played a role in helping build the 1980 Republican majority. By adopting a pro-life plank, the GOP soon offered social conservatives an electoral response to Roe.

\section{Concluding Discussion}

The Constitution pursues the dual goals of accountability and tolerance of minority rights (Peretti 1999; Barnes 2003; Lemieux and Watkins 2009). While judicial review can defend 
minorities, courts are not immune to measures of accountability. Indeed, the Constitution provides majorities with viable and effective response mechanisms (outside of direct elections) to counter-majoritarian Supreme Court decisions. In this conclusion, I review these mechanisms and consider how they affect the study of American politics, especially in light of the regime politics paradigm.

\section{Response Mechanisms}

If the Court rules against the wishes of a national majority, how can that majority respond? While the Justices do not stand for election, I argue that the response mechanisms offer feasible solutions that mitigate not only the accountability problem, but also the countermajoritarian difficulty. Before recapping the responses and discussing their range of results, it is important to remind ourselves that contemporary conditions - especially divided government (Tushnet 2003), factionalization within parties (Lemieux and Lovell 2010), and polarization (Keck 2014) — might provide political safeguards (Clayton and Pickerill 2004; Pickerill and Clayton 2004) that lessen the likelihood of a consolidated majority employing a given mechanism. Nevertheless, because some Court decisions truly are counter-majoritarian (Friedman 2002), the following responses are still viable options to dissatisfied majorities.

First, implementation of federal policy is largely up to decentralized officeholders and bureaucrats, both of whom can obstruct implementation. In Boston, for example, local policymakers and teachers encouraged the anti-busing movement. Though local parents could not hold the Justices accountable, local officials were counted on to enforce the Court's rulings. Given the vehement opposition to busing, these local officials ignored the Court. Effective short-term resistance can be seen in three of the case studies presented here. In the immediate years after Engel, Swann, and Roe, teachers still led prayer, school boards refused to implement busing, and state legislatures worked to limit the accessibility of abortions. In sum, the local responses delayed the full short-term implementation of Court decisions

Second, the Constitution provides ample inter-branch checks and balances. For example, Congress can limit the Court's jurisdiction. Of all the cases presented here, the one with the least number of court-curbing proposals (communism) was the most successful in achieving its ends. By attacking the Court's jurisdiction, Congress effectively halted the hearing of communism cases in the docket, and then witnessed a reversal in jurisprudence. Granted, it might be the case that Congress does not affect the Court as much as it affects one or two Justices - as the communism attacks had no effect on a majority of the Court. Moreover, it could be the case that seemingly pressured Justices were already somewhat more likely to conform to congressional preferences. For instance, Frankfurter was not completely sympathetic to the free speech rights of communists. Indeed, in Dennis v. US (1951), he voted in favor of the government over suspected communists. Thus, the effectiveness of congressional court-curbing might be contingent on swing voters being mildly sympathetic to congressional preferences.

Though less dramatic, another legislative response mechanism involves tightening the purse strings, which occurred after the busing and abortion rulings. Moreover, after Swann, Presidents Nixon and Ford did not actively carry out federal busing decisions, thus showing how the executive can counter-balance the judiciary. All told, Congress and the president responded to counter-majoritarian Court decisions with prescribed institutional checks. 
Third, elections have been a common response mechanism to counter-majoritarian Court rulings. For instance, Dred Scott and the anti-New Deal decisions contributed to the rise of the Republican Party and consolidation of the Democratic Party, respectively. A similar change in the alignment of parties resulted from Court cases in the mid-20 $0^{\text {th }}$ century. The New Deal united various wings (e.g., Liberal, Southern, labor, black) of the Democratic coalition. For instance, socially conservative Southerners and blue-collar Catholics voted Democratic, so long as the Party prioritized the New Deal agenda (e.g., Agricultural Adjustment Act and Wagner Act). Secondary preferences, though, such as racial equality and moral values, split the coalition (see Cook and Polsky 2005). Put simply, by 1980, those who identified as pro-prayer, anti-busing, and pro-life probably did not vote for the Democratic Party. ${ }^{18}$ In this way, holding the Court's ideological affiliates responsible — and electing a new majority, in part, precisely because it opposed judicial rulings - is a response mechanism to a counter-majoritarian Supreme Court.

The case studies exhibit a range of results. In the communism case, the majority actually succeeded in overturning previous decisions. In the school prayer case, the majority put up short-term resistance, yet Engel still stands. In the abortion case, Roe still stands, but pro-life forces used the decision to restrict the accessibility to abortion. Altogether, since the 1960s and 1970s, conservatives have enjoyed some success in thwarting implementation of Court decisions, scaling back the rulings (or at least refusing to expand on them), and using them as a foil to win elections. It is not the case that the majority must overturn a decision in order to craft an effective response to it. Rather, the Court (and accordingly, judicial review) is just like other parts of the polity - it is subject to the forces of concurrent powers and concurrent institutions. Counter-majoritarian Supreme Court decisions can certainly stand-especially in the long-term. Indeed, there is something to be said about judicial review as a durable institution that protects minority rights. While the Justices and their rulings are not subject to simple majoritarianism (i.e., Bickel's accountability problem), exercises of judicial review are still subject to majoritarian responses. At the very least, these response mechanisms are outlets that enable majorities to have significant short- and long-term effects through non-implementation and politicization. At most, they allow majorities to pressure the Court into reversing its decisions.

\section{Is Counter-Majoritarianism Really Difficult? Is Accountability Really a Problem?}

Taken together, these response mechanisms offer effective solutions to both the countermajoritarian difficulty and the accountability problem. While Supreme Court Justices will never stand for election, the Constitution provides other response mechanisms. Local implementation, inter-branch checks, and electoral realignment are all ways of countering a counter-majoritarian decision. Defining accountability through, and only through, direct elections inaccurately reflects American democracy. The US Constitution is too multi-faceted for one to pick and choose various parts without considering the document's holistic complexity. Indeed, the framers intended for the constitutional system to work as a whole, with state governments, local officials, other branches, and elections all playing a role in the polity. Once one considers the

\footnotetext{
18 To be sure, stagflation, gasoline shortages, and the Iranian hostage situation certainly played a role in the 1980 realignment. Nevertheless, counter-majoritarian decisions definitely played a role in the rise of a Republican majority founded, in part, on social conservative values.
} 
entirety of the Constitution, it is easy to identify built-in avenues of response to countermajoritarian Court decisions.

In this way, this paper adds to the regime politics' efforts to dispel the countermajoritarian myth (Graber 2005; 2008a; 2008b). However, rather than demonstrating that rulings previously thought to be counter-majoritarian actually align with the majority coalition's preferences (Graber 1993; Gillman 2006a; Whittington 2005), it accepts that some decisions truly are counter-majoritarian. Even in these rare cases, though, majorities - at the local, legislative, and electoral levels - have response mechanisms available. Viewed negatively, the mechanisms described here call into question the commitment to judicial independence and possibly the rule of law. That is, they allow majorities to challenge the legitimacy of courts or to ignore judicial rulings. These actions can certainly have long-term consequences to the health of a constitutional system.

Yet, viewed positively, the mechanisms help the system pursue dual-perhaps competing - goals. Concerned about accountability and tolerance of minority rights (Peretti 1999; Barnes 2003; Lemieux and Watkins 2009), the Constitution seeks an unelected judiciary that can protect rights, but also maintains some accountability to the rest of the constitutional system. And while we rightfully laud judicial efforts to uphold the tolerance of minority rights (e.g., Loving $v$. Virginia), perhaps we should also understand the institutional mechanisms that protect against a group of unelected judges.

Again, while those mechanisms are not the same as direct election, they do serve as an effective substitute. On the whole, given their accessibility and effectiveness, one could argue that these mechanisms do hold the Supreme Court accountable. At the very least, there is no accountability "problem," the perception of which arises from too narrow a definition of accountability. The judiciary is like any other part of the complex system of American constitutionalism. The counter-majoritarian difficulty is not difficult; it just means the Court must work with and against other institutions. 


\section{References}

Ackerman, Bruce. 2005. The Failure of the Founding Fathers: Jefferson, Marshall, and the Rise of Presidential Democracy. Cambridge, MA: The Belknap Press of Harvard University Press.

Barnes, Jeb. 2011. Dust-Up: Asbestos Litigation and the Failure of Common Sense Reform. Washington, DC: Georgetown University Press.

Barnes, Jeb. 2007. "Bringing the Courts Back In: Interbranch Perspectives on the Role of Courts in American Politics and Policy Making." Annual Review of Political Science 10: 25-43.

Barnes, Jeb. 2003. "Congressional Compromise on Election Reform: A Look Forward and Backward." In After 2000: The Politics of Election Reform, ed. Ann N. Crigler, Marion R. Just, and Edward J. McCaffery, 117-132. Oxford: Oxford University Press.

Barnes, Jeb, and Thomas F. Burke. 2015. How Policy Creates Politics: Rights, Courts, Litigation, and the Struggle over Injury Compensation. New York: Oxford University Press.

Beck, Glenn. 2008. "Frightening Obama." 27 October 2008. glennbeck.com.

Bickel, Alexander M. 1962. The Least Dangerous Branch: The Supreme Court at the Bar of Politics. New York: Bobs-Merrill Co.

Blake, Judith. 1977. "The Supreme Court's Abortion Decisions and Public Opinion in the United States." Population and Development Review 3: 50.

Bork, Robert H. 1996. Slouching Towards Gomorrah: Modern Liberalism and American Decline. New York: Regan Books.

Bridge, Dave. 2014. "Presidential Power Denied: A New Model of Veto Overrides Using Political Time." Congress \& the Presidency 41: 149-166.

Buchanan, Patrick. 1972. “Assault Strategy.” Memorandum to John Mitchell. 6 June 1972. Buchanan, Patrick. 1971. "The Muskie Watch.” Memorandum for the President. 24 March 1971. Burke, Thomas F., and Jeb Barnes. 2009. "Is There an Empirical Rights Literature?" Studies in Law, Politics, \& Society 48: 69-91.

Choper, Jesse H. Judicial Review and the National Political Process: A Functional

Reconsideration of the Role of the Supreme Court. Chicago: University of Chicago Press.

Clark, Tom S. 2010. The Limits of Judicial Independence. New York: Cambridge University Press.

Clayton, Cornell W., and J. Mitchell Pickerill. 2004. "Guess What Happened on the Way to Revolution? Precursors to the Supreme Court's Federalism Revolution.” Publius 34: 85114.

Congressional Record, 1973.

Congressional Record, 1962.

Congressional Record, 1958.

Cook, Daniel M., and Andrew J. Polsky. 2005. "Political Time Reconsidered: Unbuilding and Rebuilding the State under the Reagan Administration." American Politics Research 33: 577-605.

Crockett, David A. 2002. The Opposition Presidency: Leadership and the Constraints of History. College Station, TX: Texas A\&M University Press. 
Dahl, Robert A. 2003. How Democratic is the American Constitution? New Haven, CT: Yale University Press.

Dahl, Robert A. 1957. "Decision-Making in a Democracy: The Supreme Court as a National Policy-Maker." Journal of Public Law 6: 293.

"Democratic Platform of 1972." americanpresidency.org.

Dierenfield, Bruce J. 2007. The Battle over School Prayer: How Engel v. Vitale Changed America. Lawrence, KS: University Press of Kansas.

"Dividing the Democrats." 1971. Memorandum to the Attorney General H.R. Haldeman. 5 October 1971.

Dowd, Maureen. 2012. "Men in Black." 3 April 2012. nytimes.com.

Dolbeare, Kenneth M., and Phillip E. Hammond. 1971. The School Prayer Decisions From Court Policy to Local Practice. Chicago: University of Chicago Press.

Engel, Stephen. 2011. American Politicians Confront the Courts: Opposition Politics and Changing Responses to Judicial Power. New York: Cambridge University Press.

Ely, John Hart. 1981. Democracy and Distrust: A Theory of Judicial Review. Cambridge, MA: Harvard University Press.

Ford, Gerald. "The President's News Conference." 9 October 1974. americanpresidency.org.

Friedman, Barry. 2002. "The Birth of an Academic Obsession: The History of the Countermajoritarian Difficulty, Part Five." Yale Law Journal 112: 153-259.

Gallup. 1963. "The Gallup Poll."

Gallup. 1971. "The Gallup Poll."

Gallup. 1972. "The Gallup Poll.”

Gallup. 1973. "The Gallup Poll."

Gillman, Howard. 2006a. "Regime Politics, Jurisprudential Regimes, and Unenumerated Rights." University of Pennsylvania Journal of Constitutional Law 9: 107-119.

Gillman, Howard. 2006b. "Robert G. McCloskey, Historical Institutionalism, and the Arts of Judicial Governance.” In The Pioneers of Judicial Behavior, ed. Nancy Maveety. Ann Arbor: University of Michigan Press.

Gillman, Howard. 2004. "Martin Shapiro and the Movement from 'Old' Institutionalist Studies to 'New' Institutionalist Studies in Public Law." Annual Review of Political Science 7: 363-382.

Gillman, Howard. 2002. "How Political Parties Can use the Courts to Advance Their Agendas: Federal Courts in the United States, 1875-1891." American Political Science Review 96: 511-524.

Gottfried, Paul. 1992. The Conservative Movement. Twayne Publishers.

Graber, Mark A. 2008a. "The Countermajoritarian Difficulty: From Congress to the Courts to Constitutional Order." Annual Reviews in Law and Social Science 4: 361.

Graber, Mark A. 2008b. "Regime Politics and the Countermajoritarian Problem." Balkinization Blog. balkin.blogspot.com.

Graber, Mark A. 2005. “Constructing Judicial Review.” Annual Review of Political Science 8: 446.

Graber, Mark A. 1993. "The Nonmajoritarian Difficulty: Legislative Deference to the Judiciary." Studies in American Political Development 7: 35-73. 
Hall, Matthew E.K. 2011. The Nature of Supreme Court Power. New York: Cambridge University Press.

Henshaw, Stanley K., Jacqueline Darroch Forrest, and Ellen Blaine. 1984. "Abortion Services in the United States, 1981 and 1982." Family Planning Perspectives 17: 90-96.

Hillygus, D. Sunshine, and Todd G. Shields. 2008. The Persuadable Voter: Wedge Issues in Presidential Campaigns. Princeton, NJ: Princeton University Press.

Keck, Thomas M. 2014. Judicial Politics in Polarized Times. Chicago: University of Chicago Press.

Keck, Thomas M., and Kevin J. McMahon. Forthcoming. "Why Roe Still Stands: Abortion Law, the Supreme Court, and the Republican Regime." Studies in Law, Politics, \& Society.

Kernell, Samuel. 2006. Going Public. Washington, DC: CQ Press.

Klarman, Michael. "Rethinking the Civil Rights and Civil Liberties Revolutions." Virginia Law Review 82: 1-67.

K'Meyer, Tracy Elaine. 2013. From Brown to Meredith: The Long Struggle for School Desegregation in Louisville, Kentucky, 1954-2007. Chapel Hill, NC: The University of North Carolina Press.

Lemieux, Scott E., and George Lovell. 2010. "Legislative Defaults: Interbranch Power Sharing and Abortion Politics." Polity 42: 210-243.

Lemieux, Scott E., and David J. Watkins. 2009. "Beyond the 'Countermajoritarian Difficulty': Lessons from Contemporary Democratic Theory.” Polity 41: 30-62.

Levinson, Sanford. 2008. Our Undemocratic Constitution. Oxford: Oxford University Press.

Lovell, George. 2003. Legislative Deferrals: Statutory Ambiguity, Judicial Power, and American Democracy. New York: Cambridge University Press.

Mason, Robert. 2004. Richard Nixon and the Quest for a New Majority. Chapel Hill, NC: University of North Carolina Press.

“Mayor Asks Federal Help in Boston School Dispute." The Bulletin. 10 October 1974. news.google.com.

McCloskey, Robert G. 2000. The American Supreme Court. Chicago: University of Chicago Press.

McMahon, Kevin J. 2011. Nixon's Court. Chicago: University of Chicago Press.

McMahon, Kevin J. 2004. Reconsidering Roosevelt on Race: How the Presidency Paved the Road to Brown. Chicago: University of Chicago Press.

Metcalf, George R. 1983. From Little Rock to Boston: The History of School Desegregation. Westport, CT: Greenwood Press.

Miles, Michael W. 1980. The Odyssey of the American Right. New York: Oxford University Press.

Nash, George H. 1976. The Conservative Intellectual Movement in America Since 1945. New York: Basic Books.

National Opinion Research Center, 1954. "The Communism, Conformity, and Civil Liberties Study."

Newman, Roger K. 2001. "The Warren Court and American Politics: An Impressionistic Appreciation." Constitutional Commentary 18: 661-698.

Nichols, Curt. 2012. "The Presidential Ranking Game: Critical Review and Some New 
Discoveries." Presidential Studies Quarterly 42: 275-299.

Nichols, Curt, Dave Bridge, and Adam Carrington. 2014. "Court-Curbing via Attempt to Amend the Constitution: An Update of Congressional Attacks on the Supreme Court from 19551984." Justice Systems Journal: 1-13.

Nixon, Richard. 1972a. “The President's News Conference.” 22 June 1972. americanpresidency.org.

Nixon, Richard. 1972b. "Remarks and Question-and-Answer Session.” 30 April 1972. americanpresidency.org.

Nixon, Richard 1972c. “The President's News Conference.” 5 October 1972. americanpresidency.org.

Nixon, Richard. 1971. "Statement about the Busing of Schoolchildren." 3 August 1971. americanpresidency.org.

Obama, Barack. 2012. "News Conference." 2 April 2012. americanpresidency.org.

Peretti, Terri Jennings. 1999. In Defense of a Political Court. Princeton, NJ: Princeton University Press.

Pickerill, J. Mitchell, and Cornell W. Clayton. 2004. "The Rehnquist Court and the Political Dynamics of Federalism." Perspectives on Politics 2: 233-248.

Phillips, Kevin P. 1972a. "School Busing and Public Opinion.” The Bryan Times 4 March 1972. Phillips, Kevin P. 1972b. "How Nixon Will Win." New York Times Magazine 6 August 1972: 8. Powe, Jr. Lucas A. 2000. The Warren Court and American Politics. Cambridge, MA: The Belknap Press of Harvard University Press.

Pratt, Robert A. 1992. The Color of Their Skin: Education and Race in Richmond, Virginia, 1954-89. Charlottesville, VA: University Press of Virginia.

"Republican Party Platform of 1972." americanpresidency.org.

"Republican Party Platform of 1976." americanpresidency.org.

Romney, Mitt. 2012. "Values: Abortion." nowcomment.com.

Rosenberg, Gerald N. 1992. "Judicial Independence and the Reality of Political Power." Review of Politics 54: 391.

Rosenberg, Gerald N. 1991. The Hollow Hope: Can Courts Bring About Social Change? Chicago: University of Chicago Press.

Rouse, Frank. 1997. "Interview." Raleigh News \& Observer 6 July 1997. sohp.org.

Ryan, John Barry, and Caitlin Milazzo. 2014. "The South, the Suburbs, and the Vatican Too: Explaining Partisan Change Among Catholics." Political Behavior.

Scalia, Antonin. 1998. A Matter of Interpretation: Federal Courts and the Law. Princeton, NJ: Princeton University Press.

Schick, Allen. 1982. "How the Budget Was Won and Lost." In President and Congress: Assessing Reagan's First Year, ed. Norman J. Ornstein, Washington, DC: American Enterprise Institute for Public Policy Research.

Segretti, Donald H. 1973. "Testimony before U.S. Senate Select Committee on Presidential Campaign Activities." 3 October 1973.

Skowronek, Stephen. 2011. Presidential Leadership in Political Time: Reprise and Reappraisal. Lawrence, KS: University Press of Kansas.

Shapiro, Martin. 1964. Law and Politics in the Supreme Court: New Approaches to Political 
Jurisprudence. New York: Free Press of Glencoe.

Silverstein, Gordon. 2009. Law's Allure: How Law Shapes, Constrains, Saves, and Kills Politics. New York: Cambridge University Press.

Taylor, Steven J. L. 1998. Desegregation in Boston and Buffalo: The Influence of Local Leaders. Albany, NY: State University of New York Press.

Theoharis, Jeanne F. 2001. "We Saved the City': Black Struggles for Educational Equality in Boston, 1960-1976." Radical History Review. 81: 61-93.

Tushnet, Mark. 1993. The Warren Court in Historical and Political Perspective. Charlottesville, VA: The University of Virginia Press.

Tushnet, Mark. 2003. The New Constitutional Order. Princeton: Princeton University Press. Warren, Earl. 1977. The Memoirs of Chief Justice Earl Warren. New York: Doubleday.

Whittington, Keith E. 2005. “'Interpose Your Friendly Hand': Political Supports for the Exercise of Judicial Review by the United States Supreme Court.” American Political Science Review 99: 1-14.

Williams, Daniel K. 2010. God's Own Party: The Making of the Christian Right (Oxford: Oxford University Press.

Woods, Jeff. 2004. Black Struggle, Red Scare: Segregation and Anti-Communism in the South, 1948-1968. Baton Rouge: Louisiana State Press.

\section{Cases Cited}

Barenblatt v. United States, 360 U.S. 109 (1959).

Bradley v. Milliken, 345 F. Supp. 914 (1972 U.S. Dist)

Brown v. Board of Education, 347 U.S. 483 (1954).

Chamberlin v. Public Instruction Board, 377 U.S. 402 (1964).

Cole v. Young, 351 U.S. 536 (1956).

Dayton v. Brinkman, 433 U.S. 406 (1977).

Dennis v. US, 341 U.S. 494 (1951).

DeSpain v. DeKalb, 384 F. $2^{\text {nd }} 836$ (1967).

Dred Scott v. Sandford, 60 U.S. 393 (1857).

Engel v. Vitale, 370 U.S. 421 (1962).

Evans v. Buchanan, 393 F Supp. 428 (1975).

Jencks v. United States, 353 U.S. 657 (1957).

Konigsberg v. State Bar of California, 366 U.S. 36 (1961).

Loving v. Virginia, 388 U.S. 1 (1967).

Pennsylvania v. Nelson, 350 U.S. 497 (1956).

Roe v. Wade, 410 U.S. 113 (1973).

Schware v. Board of Bar Examiners, 353 U.S. 232 (1957).

Service v. Dulles, 354 U.S. 363 (1957).

Slowchower v. Board of Education, 350 U.S. 551 (1956).

Swann v. Charlotte-Mecklenburg Board of Education, 402 U.S. 1 (1970).

Sweezy v. New Hampshire, 354 U.S. 234 (1957).

Uphaus v. Wyman, 360 U.S. 72 (1959). 
US v. Board of Commissioners, 332 F. Supp 655 (S.D. Ind. 1971).

Watkins v. United States, 354 U.S. 178 (1957).

Yates v. United States, 354 U.S. 298 (1957). 


\begin{tabular}{|c|c|c|}
\hline & Yea & Nay \\
\hline \multicolumn{3}{|c|}{ Communism Court-Curbing (House, 1958) } \\
\hline Republicans & 142 & 44 \\
\hline Southern Democrats & 94 & 1 \\
\hline Northern Democrats & 13 & 102 \\
\hline \multicolumn{3}{|c|}{ Communism Court-Curbing (Senate, 1958) } \\
\hline Republicans & 14 & 24 \\
\hline Southern Democrats & 3 & 16 \\
\hline Northern Democrats & 24 & 0 \\
\hline \multicolumn{3}{|c|}{ School Prayer Amendment (Senate, 1966) } \\
\hline Republicans & 27 & 3 \\
\hline Southern Democrats & 15 & 3 \\
\hline Northern Democrats & 7 & 31 \\
\hline \multicolumn{3}{|c|}{ School Prayer Amendment (House, 1971) } \\
\hline Republicans & 138 & 26 \\
\hline Southern Democrats & 50 & 12 \\
\hline Northern Democrats & 52 & 135 \\
\hline \multicolumn{3}{|c|}{ Postpone Busing (House, 1971) } \\
\hline Republicans & 125 & 20 \\
\hline Southern Democrats & 43 & 15 \\
\hline Northern Democrats & 66 & 89 \\
\hline \multicolumn{3}{|c|}{ Defund Busing (House, 1971) } \\
\hline Republicans & 157 & 27 \\
\hline Southern Democrats & 52 & 8 \\
\hline Northern Democrats & 159 & 5 \\
\hline
\end{tabular}




\begin{tabular}{|l|c|c|}
\multicolumn{3}{|c|}{ Abortion Right of Conscience (House, 1973) } \\
\hline Republicans & 157 & 27 \\
\hline Southern Democrats & 57 & 12 \\
\hline Northern Democrats & 186 & 1 \\
\hline \multicolumn{2}{|c|}{ Abortion Right of Conscience (Senate, 1973) } \\
\hline Republicans & 40 & 0 \\
\hline Southern Democrats & 19 & 1 \\
\hline Northern Democrats & 31 & 0 \\
\hline \multicolumn{1}{|c|}{ Defund abortion legal services (House, 1973) } \\
\hline Republicans & 153 & 10 \\
\hline Southern Democrats & 52 & 52 \\
\hline Northern Democrats & 95 & 28 \\
\hline \multicolumn{2}{|c|}{ Defund abortion services (House, 1976) } \\
\hline Republicans & 94 & 34 \\
\hline Southern Democrats & 38 & 105 \\
\hline Northern Democrats & 75 & 5 \\
\hline
\end{tabular}

